\title{
Phenotypic Performance of Rice (Oryza sativa L.) Populations Induced by the MNU Mutant on the Adaptive Characteristics
}

\author{
Truong Thi Tu Anh ${ }^{1, a}$, Tran Dang Xuan ${ }^{1, b^{*}}$, \\ Can Thu Huong ${ }^{1}$ and Tran Dang Dat ${ }^{2, \mathrm{c}}$ \\ ${ }^{1}$ Graduate School for International Development and Cooperation, Hiroshima University, \\ Hiroshima, Japan \\ ${ }^{2}$ Khai Xuan Co. Ltd., Cau Giay District, Hanoi, Vietnam \\ atuanhbp@gmail.com, ’btdxuan@hiroshima-u.ac.jp, ckhaixuanstudy@gmail.com
}

\begin{abstract}
Keywords: MNU-induced mutation, wide-adapted, mutants, distribution, rice breeding
\end{abstract}
\begin{abstract}
Mutation is an impressive method to induce potent characteristics in rice breeding programs. Evaluation of the phenotypic performance in mutant populations is important to examine the effectiveness of mutation. In this study, two rice mutant populations generated from MNU ( $N$ methyl- $N$-Nitrosourea)-induced mutation were used to evaluate their phenotypes. The results showed that all of varieties and mutants expressed their ability to adapt with new environmental condition via the expression of agronomic traits. Grain yield of them ranged from 6.18 to 10.70 tons/ha. In general, population BC15TB $\times$ SKLo performed their best characters. The distribution of related traits to grain yield and amylose content were also different from each population. These results indicated that mutants expressed better characters than their parents. This study provided general information on the phenotype of rice mutants and varieties in the new environment and revealed the better-adapted characteristic of rice mutants. Findings of this study confirmed the efficacy of MNU in rice breeding and promising new potential mutants for rice breeding.
\end{abstract}

\section{Introduction}

Rice is an annual plant and has enormous importance in the world due to its nutritional value [1]. Rice is recognized as the key cereal crop consumed almost exclusively by human beings, and approximately fifty percent of the world's population based on rice as their principal food [2]. Most of the world's rice (about 90\%) was produced and consumed in the Asia region with 100,000 entries from twenty wild species. Among cultivated rice, Oryza sativa originated from Asia has the most contribution to the worldwide production [3]. Rice breeding plays an important role in increasing food production [4] for a rising global population. To date, the average of rice production is around 5.34 tons/ha [5], and it is necessary to enhance rice production for encounter with the consequent rising demands. Previous study indicated that increasing rice yield and creating superior rice to ensure food security are therefore the urgent challenges [6]. Tremendous progress has been conducted to optimal rice protocol [2], among of them, mutation is a prominent strategy for rice breeding.

As a heritable alteration in genetic material, mutation created variation allowing the organism to adjust and adapt to their environment, and this variation can be transferred from parent to offspring [7]. Mutation was considered as a practical approach, and its positive impacts were confirmed in crop improvement in a shorter time and a reduction in cost, and it is a useful tool to isolate and develop the expected variants and resistances for breeding programs [8]. The principal goal of mutation breeding is to develop new varieties possessing high yield, better nutritional quality, and resistant to biotic and abiotic stresses [9]. Considerable progress has been made by induced mutation breeding; as a result, a total of 821 rice mutant varieties have been officially released in the world. Remarkably, more than 84 percent of rice mutant varieties are generated from Asia region, in which, China, Japan, and India are considered as the top three of the world about mutants' generation [10]. These mutants have been noted as the major crop, and they were cultivated in large areas contributed to food security [11]. 
Physical and chemical factors are mainly mutagens to create mutagenesis in plant $[6,9,12]$. Chemical mutagens can provide a very high mutation frequency; moreover, they were very easy to use without specialized equipment [13]. Therefore, most of the mutant populations of rice, maize, barley, and sorghum were created by chemical mutagens [6]. Induced mutagenesis is admitted as a potential tool to improve crop characters within a shorter time than traditional breeding, and numerous mutant alleles are sources of genetic diversity [8]. This study was conducted to characterize each mutant's population generated by MNU-induced mutation, examine their wide-adapted ability via phenotypic assessment, and to evaluate the variation among population via the distribution of each related character to grain yield and amylose content.

\section{Materials and Methods}

\section{Rice materials}

Two populations including mutant lines ( $\mathrm{F}_{2}$ generation) and their parents (rice cultivars) were used to examine in this study. All of the cultivars are Indica subtype. Population 1 included DT84, $\mathrm{M}_{2}$-Bao thai, and the $\mathrm{F}_{2}$ generation of Bao thai/DT84, and population 2 consisted of BC15TB, SKLo, and the $\mathrm{F}_{2}$ generation of $\mathrm{BC} 15 \mathrm{~TB} / \mathrm{SKL}$. Rice materials' information was listed in Table 1. Rice mutants were released from original cultivars by MNU (N-methyl-N-Nitrosourea) treatment under a novel chemical mutation, noted as "Respiration Mutation" as described in the recent study [14]. Rice seeds were treated with MNU at a low concentration in a hermetic condition in a duration of three months. After that, they were collected and stored at $5{ }^{\circ} \mathrm{C}$ in the dark until further use.

\section{Field evaluation}

Seedlings of mutants and varieties were transplanted in May and harvested in early November 2016 at a rice field affiliated to Hiroshima University, Hiroshima, Japan $\left(85^{\circ} \mathrm{E}, 34^{\circ} 23^{\prime} 41^{\prime}\right.$ ' $\mathrm{N}$ $132^{\circ} 43^{\prime} 5^{\prime}$ 'E, $200 \mathrm{~m}$ Elevation). Before cultivated at the field, all of the rice seeds were treated as described in Anh et al. [14]. Rice was soaked in $\mathrm{NaOCl}(0.1 \%)$ for 30 minutes and then washed with distilled water. These seeds were placed in beakers and kept in a plant growth chamber at $30{ }^{\circ} \mathrm{C}$ in three days. The germinated seeds were transferred into plastic trays with soil and moved to a greenhouse. After twenty days, seedlings were transplanted into the rice field. Rice was arranged as a randomized complete block design with three replications. Plant spacing was assigned as $15 \times$ $20 \mathrm{~cm}$ with one seedling per hill. Standard fertilizer was applied in three times by hand broadcasting, before transplanting, during tiller formation, and during panicle initiation stage. Weeding was also controlled by hands. Standard agronomic practices were used as rice characteristics' recommendations.

\section{Phenotypic characters assessment}

Phenotypic characters were evaluated in this study including panicles number per plant (NP), panicle length (PL), 1000-grain weight (KGW), full-grain per plant (FGP), grain yield per hectare (GY), grain length (GL), grain width (GW), and grain length to width ratio (LWR), amylose content (AC), protein content (PC), and lipid content (LC). To collect data, plants were randomly chosen without border plants.

\section{Rice grain yield measurement}

Grain yield characteristics including panicles number per plant (NP), panicle length (PL), 1000grain weight (KGW), full grains per plant (FGP), grain yield per hectare (GY) were recorded at the maturity stage. Panicle length (PL) was measured in centimeters from panicle base to the tip. The weight of 200 grains was used to calculate the weight of 1000 grains. Ten rice-grains were randomly selected and measured grain length (GL), grain width (GW), and grain length to width ratio (LWR). The value of grain length, grain width, and grain length to width ratio were recorded by millimeters. Grain yield per hectare was calculated by grain yield per square meter 


\section{Chemical quality character evaluation}

Rice grains were dried by oven until getting expected moisture (14\%), and then they were dehusked by an Automatic Rice Husker machine (model TR-250, Japan). After that, amylose content (AC), protein content (PC), and lipid content (LC) were measured by PGC Shizuoka Seiki PS-500 machine (version 2-12, Japan). The final values of them were the average of five times measurement.

\section{Data analysis}

The phenotypic data were analyzed by SPSS 20.0 package (SPSS Inc., Chicago, IL, USA) and Minitab version 16 software (Minitab Inc., Stage, PA, USA). The contribution of the related traits on grain yield and amylose content was estimated by regression analysis.

Table 1. List of rice materials.

\begin{tabular}{|c|c|c|}
\hline $\mathbf{P}$ & Origins & Descriptions \\
\hline 1 & $\mathrm{M}_{2}$-Bao thai & $\begin{array}{c}\text { The origin Bao Thai cultivar from China with good quality, } \\
\text { cold tolerance, growth duration ranged from } 160-170 \\
\text { days. It was cultivated in Northern Midland and } \\
\text { Mountainous region in Vietnam }\end{array}$ \\
\hline 1 & DT84 & Traditional rice with good quality in the North of Vietnam \\
\hline 1 & $\mathrm{M}_{2}$-DT84/M2-Bao thai & $\begin{array}{l}\text { These materials were } \mathrm{F}_{2} \text { generation and induced with MNU. } \\
\text { They were originated from crossing between DT84 (female } \\
\text { parent) and } \mathrm{M}_{2} \text {-Bao thai (male parent). }\end{array}$ \\
\hline 2 & SKLo & A high yield cultivar, widely cultivated in Vietnam \\
\hline 2 & $\mathrm{BC} 15 \mathrm{~TB}$ & $\begin{array}{l}\text { Rice cultivar possesses good quality, high yield, resistance } \\
\text { to bacterial leaf blight and brown planthopper, high } \\
\text { adaptability, growth duration varied from } 130-138 \text { days in } \\
\text { spring season, and } 110-115 \text { days in another season, widely } \\
\text { cultivated in Vietnam }\end{array}$ \\
\hline 2 & $\mathrm{M}_{2}-\mathrm{BC} 15 \mathrm{~TB} / \mathrm{SKLo}$ & $\begin{array}{l}\text { These materials were } \mathrm{F}_{2} \text { generation and treated by MNU } \\
\text { mutagen. They were generated from crossing between } \\
\text { BC15TB (Female parent) and SKLo (male parent). }\end{array}$ \\
\hline
\end{tabular}

P: population

\section{Results}

\section{Field performance of rice mutant populations}

The results of the phenotypic analysis of mutant populations were presented in Table 2 . The results showed a wide variation between population 1 and 2 . The average grain yield of population 1 diverged from population 2, these values ranged from 7.23 to 10.70 tons $/ \mathrm{ha}$. $\mathrm{P}_{2}\left(\mathrm{M}_{2}\right.$-BC15TB/SKLo, $\mathrm{BC} 15 \mathrm{~TB}, \mathrm{SKLo})$ gained higher yield (10.70 tons/ha) than $\mathrm{P}_{1}\left(\mathrm{M}_{2}\right.$-Bao thai, DT84, DT84/ $\mathrm{M}_{2}-\mathrm{Bao}$ thai) 7.23 tons/ha. Panicle length ranged from 24.62 to $26.12 \mathrm{~cm}$. The panicle length of $\mathrm{P}_{1}$ was $24.62 \mathrm{~cm}$, while the panicle length of $\mathrm{P}_{2}$ was $26.12 \mathrm{~cm}$. The 1000 -grain weight varied from 21.78 to 22.19 gr. The higher value of 1000 -weight grain was recorded in $\mathrm{P}_{2}\left(22.19\right.$ gr), the KGW of $\mathrm{P}_{1}$ was 21.78 gr. Both population 1 and population 2 had long grain size. Their grain length were longer than $5.50 \mathrm{~mm}$, and their grain length to width ratio were greater than $2.00 \mathrm{~mm}$. Their size were $5.98 ; 2.49$ $\mathrm{mm}\left(\mathrm{P}_{1}\right)$ and $6.19 ; 2.67 \mathrm{~mm}\left(\mathrm{P}_{2}\right)$.

The results of chemical properties also showed in Table 2, the average value of amylose content of two populations ranged from 22.33 to $24.11 \%$, in which $\mathrm{P}_{2}$ had a higher value $(24.11 \%)$ than $\mathrm{P}_{1}$ $(22.33 \%)$. Protein content value of population 1 differed from population 2 , in which $\mathrm{P}_{2}(5.32 \%)$ had lower value than $\mathrm{P}_{1}(6.78 \%)$. The average values of $\mathrm{LC}$ varied from 8.66 in $\mathrm{P}_{2}$ to $9.77 \% \mathrm{P}_{1}$. 
The phenotypic expression of each population was listed in Table 3 and Table 4 . These results showed that mutants had better values than their parents. In population 1, the yield of mutants was 7.84 tons/ha, while their parents' yields were 6.81 and 7.04 tons/ha. In population two, mutants' yield was 13.04 tons/ha; otherwise, their parents' yields were 9.76 and 9.32 tons/ha.

\section{Distribution of traits to grain yield}

The distribution of related traits to grain yield of two mutant populations was performed in Fig. 1. Results showed that grain yield completely linear increased with increasing full grain in both of two populations $(r=1)$. However, the contribution of a number of panicles and 1000-grain weight on grain yield was different from each population. The contribution of NP to GY ranged from 0.32 in $\mathrm{P}_{1}$ to $\mathrm{P}_{2}$ 0.39. There was minimal relevance between KWG and GY in both populations. KWG had a very small linear relationship to GY (in $\mathrm{P}_{1} r=0.08$; in $\mathrm{P}_{2} r=0.05$ ).

\section{Distribution of traits to amylose content}

The distribution of related traits to amylose content of mutant populations was depicted in Fig. $2 \mathrm{a}$ and $2 \mathrm{~b}$. There was an inconsistent distribution among traits to AC. The contribution of GL to AC ranged from 0.26 to 0.27 . There was negligible difference between $\mathrm{P}_{1}$ and $\mathrm{P}_{2}$, the linear contributions of GL to AC were 0.27 in $\mathrm{P}_{1}$ and 0.26 in $\mathrm{P}_{2}$. Ranged from 0.15 to 0.39 , the linear contribution of GW to $\mathrm{AC}$ was 0.39 in $\mathrm{P}_{1}$ and 0.15 in $\mathrm{P}_{2}$. The contribution of LWR to AC ranged from 0.07 to 0.43 , in which, the smaller contribution of LWR to AC was found in $\mathrm{P}_{2}(0.07)$, and the value of $\mathrm{P}_{2}$ was 0.43 . The contribution of PL to AC ranged from 0.00 to 0.09 , in which, insignificant distribution of PL to AC was noted in $\mathrm{P}_{2}(r=0.00)$, and the minimal distributions in $\mathrm{P}_{1}$ was 0.09 , respectively. The contribution of $\mathrm{PC}$ to $\mathrm{AC}$ ranged from 0.00 to 0.09 . No linear relationship between $\mathrm{PC}$ and $\mathrm{AC}(r=$ $0.00)$ was found in $\mathrm{P}_{2}$, and the low linear relationship was observed in $\mathrm{P}_{1}(r=0.09)$. The low contribution of $\mathrm{LC}$ to $\mathrm{AC}$ was considered in all populations and ranged from 0.00 to 0.14 , in which no linear relationship was noted in $\mathrm{P}_{2}(r=0.00)$, and small linear was in $\mathrm{P}_{1}(r=0.14)$.

Table 2. Descriptive statistic of phenotypic traits in mutants/varieties.

\begin{tabular}{|c|c|c|}
\hline Traits & $\mathbf{P}_{\mathbf{1}}$ & $\mathbf{P}_{\mathbf{2}}$ \\
\hline NP & $7.44 \pm 1.66 \mathrm{~b}$ & $8.59 \pm 1.44 \mathrm{a}$ \\
\hline PL & $24.62 \pm 1.12 \mathrm{~b}$ & $26.12 \pm 0.69 \mathrm{a}$ \\
\hline KWG & $21.78 \pm 1.36 \mathrm{a}$ & $22.19 \pm 0.87 \mathrm{a}$ \\
\hline GY & $7.23 \pm 1.01 \mathrm{~b}$ & $10.70 \pm 0.51 \mathrm{a}$ \\
\hline FGP & $21.91 \pm 95.7 \mathrm{~b}$ & $32.43 \pm 73.3 \mathrm{a}$ \\
\hline GL & $5.98 \pm 0.24 \mathrm{~b}$ & $6.19 \pm 1.14 \mathrm{a}$ \\
\hline GW & $2.40 \pm 0.16 \mathrm{a}$ & $2.32 \pm 0.04 \mathrm{~b}$ \\
\hline LWR & $2.49 \pm 0.24 \mathrm{~b}$ & $2.67 \pm 0.02 \mathrm{a}$ \\
\hline PC & $6.78 \pm 0.89 \mathrm{a}$ & $5.32 \pm 0.16 \mathrm{~b}$ \\
\hline AC & $22.33 \pm 1.33 \mathrm{~b}$ & $24.11 \pm 0.21 \mathrm{a}$ \\
\hline LC & $9.77 \pm 1.65 \mathrm{a}$ & $8.66 \pm 0.60 \mathrm{~b}$ \\
\hline
\end{tabular}

Each value expressed Mean \pm Standard error; a,b,c: Different letter in the same row indicated significant differences at $\mathrm{P}<0.05$ level by Fisher pairwise comparisons; $\mathrm{P}_{1}$ (Population 1) : $\mathrm{M}_{2}$-Bao thai, DT84, M2-DT84/Bao thai, $\mathrm{P}_{2}$ (Population 2): BC15TB, SKLo, M2-BC15TB/SKLo; NP: number of panicle per plant; PL: panicle length; KWG: 1000-grain weight; GY: grain yield per ha; FGP: full grain per plant; GL: grain length; GW: grain width; LWR: grain length to width ratio; PC: protein content; AC: amylose content; LC: lipid content. 
Table 3. Descriptive statistic of phenotypic traits in Population 1.

\begin{tabular}{|c|c|c|c|}
\hline Traits & Bao thai & DT84 & DT84/Bao thai \\
\hline NP & $6.50 \pm 1.80 \mathrm{~b}$ & $7.63 \pm 1.88 \mathrm{a}$ & $8.20 \pm 1.79 \mathrm{a}$ \\
\hline PL & $25.59 \pm 1.11 \mathrm{a}$ & $25.93 \pm 1.26 \mathrm{a}$ & $22.33 \pm 1.22 \mathrm{~b}$ \\
\hline GL & $5.97 \pm 0.19 \mathrm{~b}$ & $6.30 \pm 0.19 \mathrm{a}$ & $5.68 \pm 0.26 \mathrm{c}$ \\
\hline GW & $2.10 \pm 0.02 \mathrm{~b}$ & $2.29 \pm 0.12 \mathrm{~b}$ & $2.17 \pm 0.01 \mathrm{a}$ \\
\hline LWR & $2.68 \pm 0.10 \mathrm{~b}$ & $2.76 \pm 0.14 \mathrm{a}$ & $2.11 \pm 0.10 \mathrm{c}$ \\
\hline FG & $20.62 \pm 6.23 \mathrm{a}$ & $21.34 \pm 6.16 \mathrm{a}$ & $23.77 \pm 6.15 \mathrm{a}$ \\
\hline KWG & $19.88 \pm 2.38 \mathrm{~b}$ & $22.79 \pm 1.55 \mathrm{~b}$ & $22.67 \pm 1.46 \mathrm{a}$ \\
\hline GY & $6.81 \pm 2.06 \mathrm{a}$ & $7.04 \pm 2.03 \mathrm{a}$ & $7.84 \pm 2.03 \mathrm{a}$ \\
\hline PC & $5.87 \pm 1.44 \mathrm{~b}$ & $6.37 \pm 1.52 \mathrm{a}$ & $8.09 \pm 2.12 \mathrm{a}$ \\
\hline AC & $23.19 \pm 0.83 \mathrm{a}$ & $23.29 \pm 1.01 \mathrm{a}$ & $20.51 \pm 1.74 \mathrm{~b}$ \\
\hline LC & $8.70 \pm 3.14 \mathrm{~b}$ & $9.51 \pm 2.81 \mathrm{a}$ & $11.10 \pm 2.24 \mathrm{a}$ \\
\hline
\end{tabular}

a, b, c: Different letter in the same row indicated the significant differences at $P<0.05$ level by Fisher pairwise comparison. Value is the mean \pm standard deviation.

Table 4. Descriptive statistic of phenotypic traits in Population 2.

\begin{tabular}{|c|c|c|c|}
\hline Traits & BC15TB & SKLo & BC15TB/SKLo \\
\hline NP & $7.77 \pm 1.72 \mathrm{~b}$ & $6.53 \pm 1.53 \mathrm{c}$ & $11.47 \pm 2.62 \mathrm{a}$ \\
\hline PL & $26.02 \pm 079 \mathrm{~b}$ & $24.92 \pm 1.11 \mathrm{c}$ & $27.43 \pm 1.36 \mathrm{a}$ \\
\hline GL & $6.43 \pm 0.17 \mathrm{a}$ & $5.96 \pm 0.20 \mathrm{c}$ & $6.18 \pm 0.18 \mathrm{~b}$ \\
\hline GW & $2.36 \pm 0.04 \mathrm{a}$ & $2.25 \pm 0.06 \mathrm{~b}$ & $2.34 \pm 0.06 \mathrm{a}$ \\
\hline LWR & $2.73 \pm 0.09 \mathrm{a}$ & $2.64 \pm 0.10 \mathrm{~b}$ & $2.64 \pm 0.10 \mathrm{~b}$ \\
\hline FG & $29.57 \pm 8.71 \mathrm{~b}$ & $28.23 \pm 6.70 \mathrm{~b}$ & $39.60 \pm 5.20 \mathrm{a}$ \\
\hline KWG & $23.00 \pm 0.74 \mathrm{a}$ & $20.39 \pm 1.32 \mathrm{~b}$ & $23.18 \pm 0.61 \mathrm{a}$ \\
\hline GY & $9.76 \pm 2.87 \mathrm{~b}$ & $9.32 \pm 2.12 \mathrm{~b}$ & $13.04 \pm 1.72 \mathrm{a}$ \\
\hline PC & $5.26 \pm 1.07 \mathrm{a}$ & $5.37 \pm 1.70 \mathrm{a}$ & $5.32 \pm 1.55 \mathrm{a}$ \\
\hline AC & $24.46 \pm 0.25 \mathrm{a}$ & $24.17 \pm 0.5 \mathrm{~b}$ & $23.69 \pm 0.50 \mathrm{c}$ \\
\hline LC & $8.96 \pm 2.84 \mathrm{ab}$ & $7.73 \pm 2.51 \mathrm{~b}$ & $9.30 \pm 2.74 \mathrm{a}$ \\
\hline
\end{tabular}

a, b, c: Different letter in the same row indicated the significant differences at $P<0.05$ level by Fisher pairwise comparison. Data are expressed as the mean \pm standard deviation. 

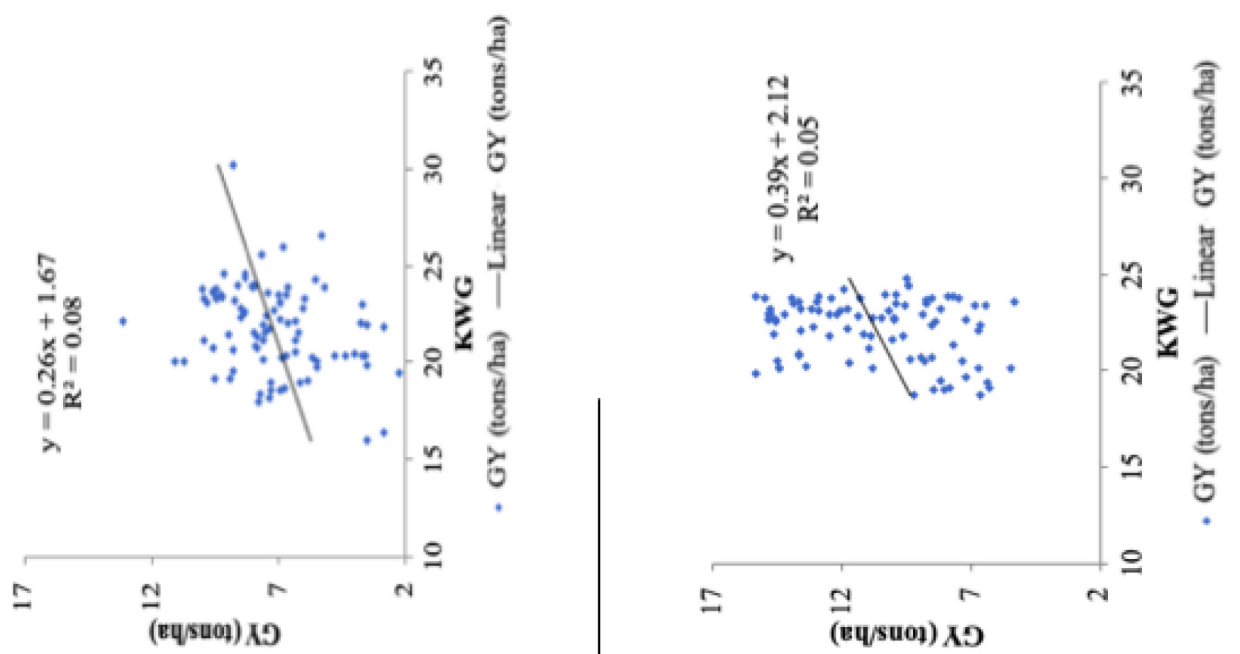

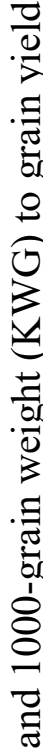
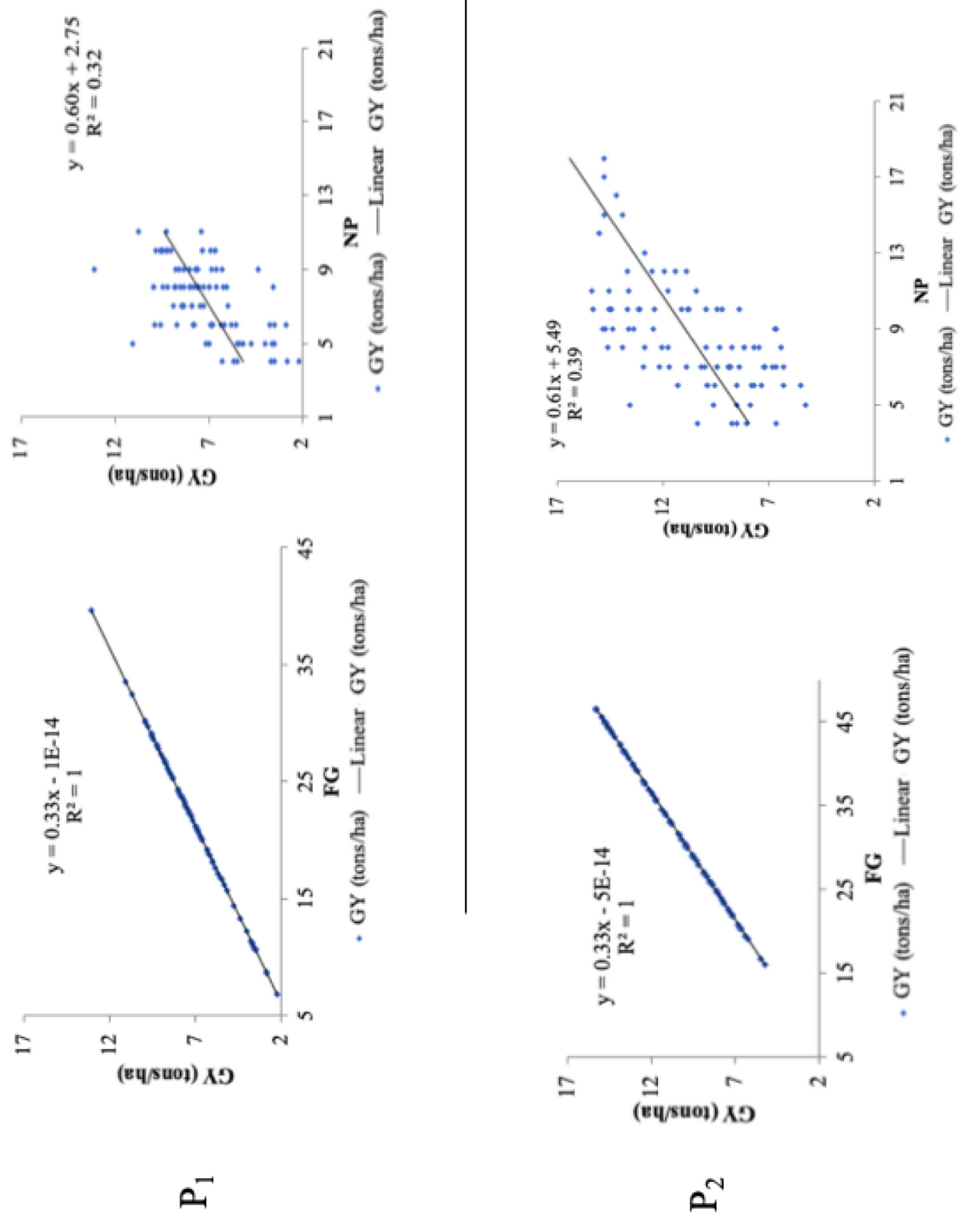

Z

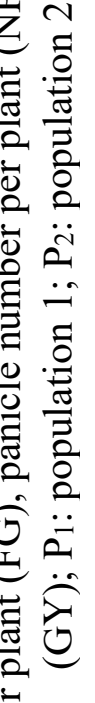

ฮั

ב⿱艹 

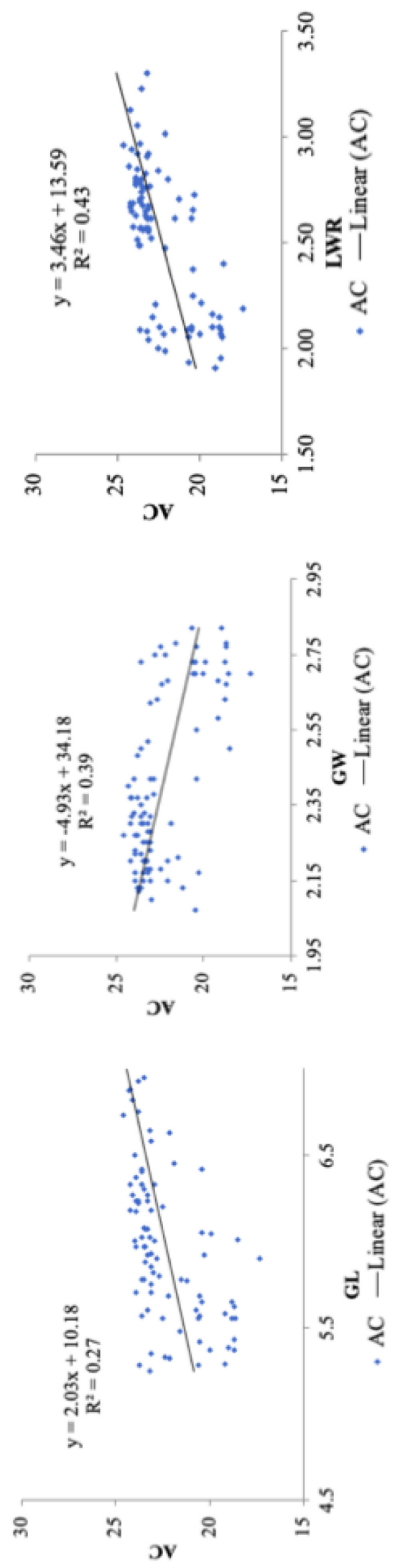

A.

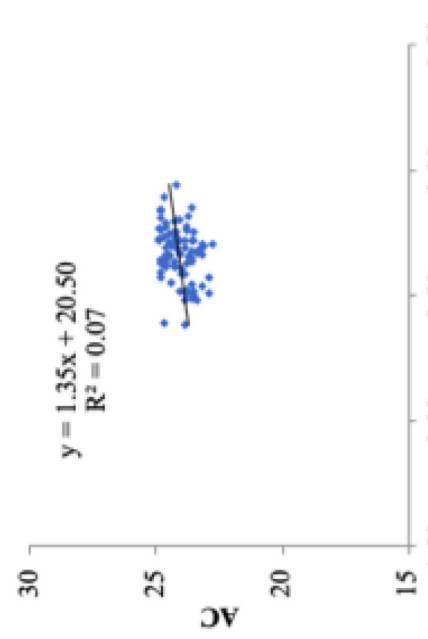

म․

-

我过

究

8

$\stackrel{\circ}{-}$

2)

.

ำ
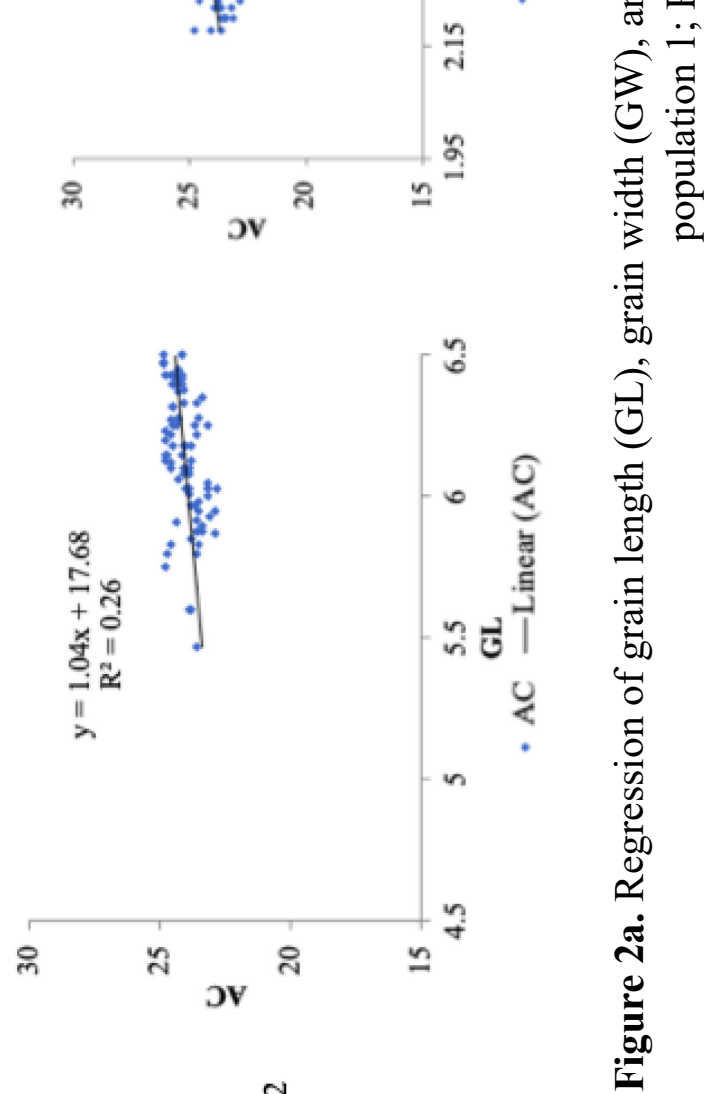

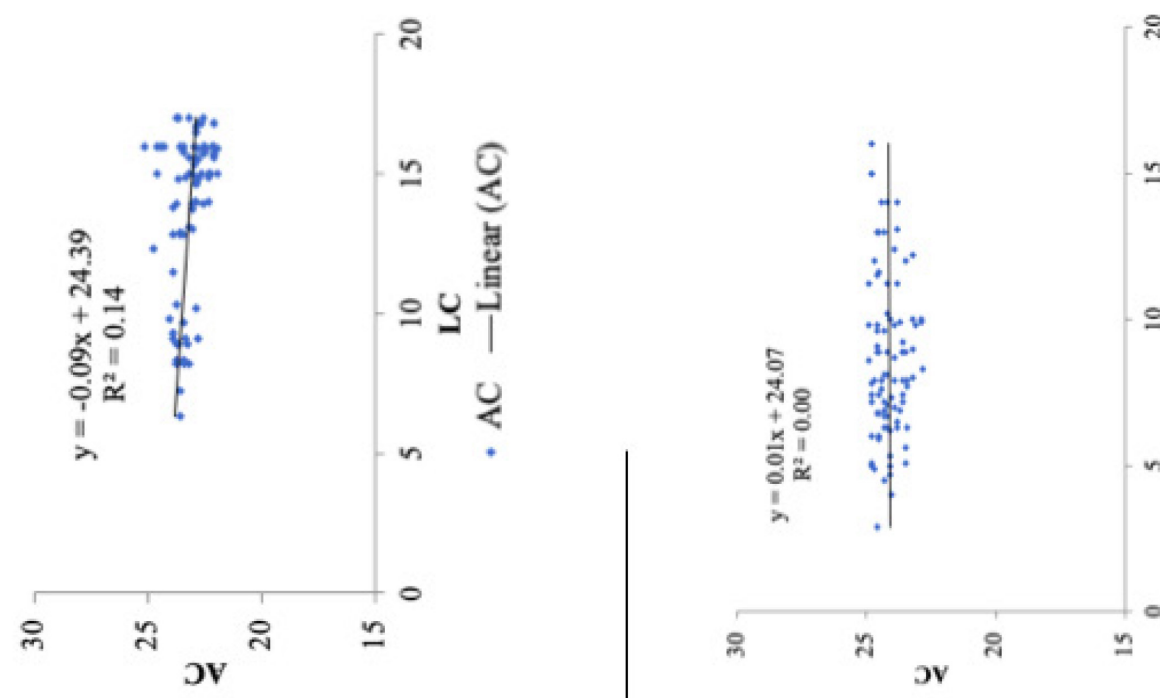

$\ddot{i}$

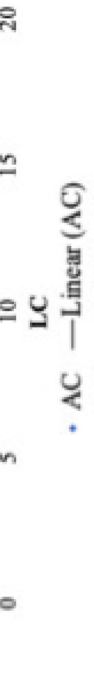

$\ddot{-}$

.ำ

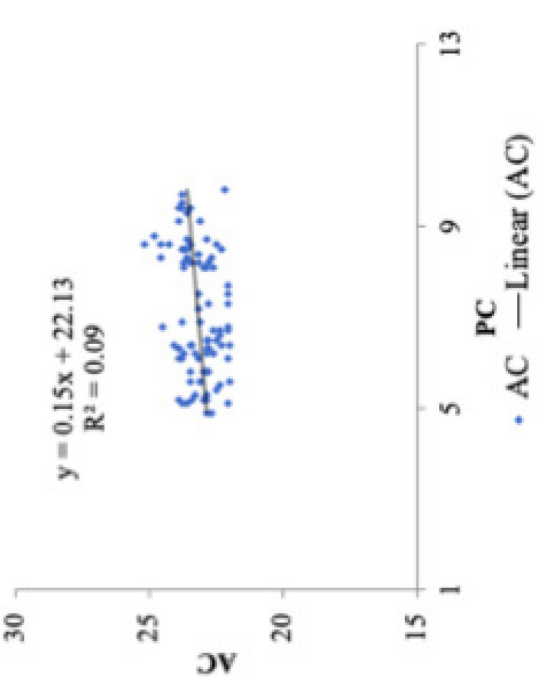

$\stackrel{m}{2}$

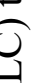




\section{Discussion}

An indisputable position of rice has recognized in human beings' daily life because the demand for rice is always necessary and undeniable. Although climate change is currently the most formidable obstacle effecting to crop productivity [6], rice production need to be risen up to more $70 \%$ in the upcoming year to fulfil the requirement of rapid growth of global population by 2050 [1]. Remarkably, mutation is considered as a sufficient method to extend particular rice characteristics [15]. Additionally, it was documented that induced mutation had more advantages to enhance elite characters than single phenotypic variation [16]. Furthermore, an unprecedented role of mutation has been clarified both in new cultivars and gene function [17]. According to FAO/IAEA database, up to now, 1825 mutants were known as better quality and higher nutritional content [18], and they have a greater impact to the economy of their area production [17]. MNU-induced mutant population was considered as a powerful source for rice breeding [19].

To screen mutant populations, field evaluation is important because a gene can be altered by induced mutations leading to change desired characters [20]. Phenotypic performance and yield expression under field condition are valuable information because these evidences will support breeding efforts more efficient and successful [21]. Wide adaptation is one of the beneficial characters of rice varieties, rice can be able to grow over large geographical regions under the alternative of agroclimatic conditions [22]. Wide adaptation is a valuable character of rice to deal with climate change in the current situation. In this study, rice varieties and MNU mutants were presented their well-adapted ability. These populations were cultivated in the summer season from May to the early November 2016, both of them expressed their adaptive ability to the environmental condition in Hiroshima, Japan through phenotypic expression although they were indica varieties. Imported to Vietnam from China since 1970s, Bao thai was characterized by high quality, adaptation, and cold tolerance, while BC15TB was generated by Thai Binh seeds company possessing high productivity. These varieties' yields in Vietnam were considered from 5.5 to 10 tons/ha. In this study, the average yield of these population was acceptable, and astonishingly, mutants had a higher yield than their parents. These results confirmed that mutant lines released from varieties performed well adaptability, and they had better characteristics compared to their parents. It can be explained that mutation created allelic variations, and these alleles were able to transfer from parent to offspring and enabled organisms to become accustomed to the environment [7].

The association among phenotypic traits is a considerable feature to select desired characteristics $[23,24]$. Our results found both consistent and inconsistent about the distribution of each trait to grain yield and $\mathrm{AC}$ in each population. In the previous study, the correlations among traits in mutants were identified [14], and the distribution of related phenotypic traits was documented in rice populations $[23,25]$. The number of panicles, full grains, and grain weight are three principal elements of grain yield, in which 1000-grain weight, is a significant trait related to grain yield [26, 27]. Conversely, this study found that full grain per plant had the highest contribution to grain yield of two populations. This result was similar to our previous study [14] and suggested that full grain will decide grain yield. Grain length, grain width, and grain length to width ratio are three main factors of grain size, and they can determine grain appearance quality [27]. Former studies found that there were correlations between grain size (appearance quality) and nutritional quality [14, 23, 25]. The distribution of grain size to AC was different on each population. This result also revealed in [24, 26], and they implicated that it was difficult to demonstrate the relationship between AC and the other traits. Additionally, a correlation between grain weight and grain size was found [26]; however, the level of correlation of them has differed from independent studies. Previous research illustrated that amylose content was regulated by $W x$ gene and the other minor QTLs [26, 28] and proposed that marker-assisted selection should be applied on that process because it was difficult to classify genotypes closely by phenotypic evaluation [29, 30].

The prior studies indicated that the interaction of genotypes and environments caused the inconsistent level of correlation coefficients among phenotypic characters, and many agronomical traits such as morphological, physiological; in addition, quality characters can be sensitive from influences of environments such as climate and soil [31-33]. The environment is one of the strong 
factors that effects to phenotypic performances, at many experimental conditions as diverse sites, various fertilizations, and weather conditions, elite cultivars will exhibit different phenotypes. In this study, mutants released by MNU-induced mutation expressed their good phenotype and they could be a promising source for rice breeding. MNU was documented as a high-frequency mutation agent, and it created point mutation and varied genome's organism $[34,35]$. Therefore, these alterations by MNU impacted on phenotypic expression because the phenotype is a result of the interaction between genotype and environment [36]. This study evaluated both individual and group characters and supplied detailed information of mutants as well as their relatives to help us better understand on mutant characteristics, the variation of mutants, the relationships of traits in two populations, and the adaptation character of rice mutants.

\section{Conclusions}

Varieties possessed well-adapted character are a priority in rice breeding under pressure of climate changes. Furthermore, rice with high productivity is apparently needed. In this study, the wide-adapted characteristic was confirmed from rice mutants generated by MNU- mutation. This research primarily revealed valuable information of MNU mutagen on the phenotype of mutants. These findings indicate that it is possible to obtain better varieties by MNU-induced mutation as compared to their parents. Further examination as marker-assisted selection (MAS) should be conducted on these mutant population to analyse the alternations in molecular levels of mutants.

\section{Conflict of Interest}

The authors declare no conflict of interest.

\section{Acknowledgements}

The authors thank the Ministry of Agriculture and Rural Development and the Ministry of the Socialist Republic of Vietnam provided a scholarship to Truong Thi Tu Anh.

\section{References}

[1] G. Shabir et al., Rice molecular markers and genetic mapping: Current status and prospects, Journal of Integrative Agriculture. 16 (2017) 1879-1891.

[2] S. Bajaj, A. Mohanty, Recent advances in rice biotechnology - Towards genetically superior transgenic rice, Plant Biotechnology Journal. 3 (2005) 275-307.

[3] S.S. Virmani, M. Ilyas-Ahmed, Rice breeding for sustainable production, in: M.S. Kang, P.M. Priyadarshan (Eds.), Breeding Major Food Staples, Blackwell Publishing Inc., Iowa, USA, 2007, pp. 109-140.

[4] B.C.Y. Collard, D.J. Mackill, Marker-assisted selection: an approach for precision plant breeding in the twenty-first century, Philosophical Transactions of the Royal Society B. 363 (2008) 557-572.

[5] IRRI, World Rice Statistics: On-line Query Facility. Available: http://ricestat.irri.org:8080/wrsv3/entrypoint.htm.

[6] M.A.J. Parry et al., Mutation discovery for crop improvement, Journal of Experimental Botany. 60 (2009) 2817-2825.

[7] R.J. Brooker, Gene mutation and DNA repair, in: P.E. Reidy (Eds.), Genetics analysis and principles, McGraw-Hill, New York, USA, 2009, pp. 424-443.

[8] Y. Oladosu et al., Principle and application of plant mutagenesis in crop improvement: A review, Biotechnology and Biotechnological Equipment. 30 (2016) 1-16. 
[9] Q.Y. Shu, B.P. Forster, H. Nakagawa. Principles and applications of plant mutation breeding, in: Q.Y. Shu, B.P. Forster, H. Nakagawa (Eds.), Plant mutation breeding and biotechnology, CABI Publishing, Wallingford, 2012, pp. 301-324.

[10] The Joint FAO/IAEA Mutant Varieties Database. Available: https://mvd.iaea.org/.

[11] P. Suprasanna, S.J. Mirajkar, S.G. Bhagwat, Induced mutations and crop improvement, in: B. Bahadur et al. (Eds.), Plant Biology and Biotechnology, Springer, New Delhi, 2015, pp. 59617.

[12] A. Riaz, A. Gul, Plant mutagenesis and crop improvement, in: K. Hakeem (Eds.), Crop Production and Global Environmental Issues, Springer, Cham, 2015, pp. 181-209.

[13] P. Sikora et al., Mutagenesis as a tool in plant genetics, functional genomics, and breeding. International journal of plant genomics. 13 (2011).

[14] T.T.T. Anh et al., Identification of phenotypic variation and genetic diversity in rice (Oryza sativa L.) mutants, Agriculture. 8 (2018) 30.

[15] E.P. Guimarães, Rice breeding, in: M.J. Carena (Ed.), Cereals, the Banks and the Italian Economy, Springer, New York, USA, 2009, pp. 99-126.

[16] B.S.Ahloowalia, M, Maluszynski, K. Nichterlein, Global impact of mutation-derived varieties, Euphytica. 1352 (2004) 187-204.

[17] R. Pathirana, Plant mutation breeding in agriculture, CAB previews: Perspectives in Agriculture, Veterinary Science, Nutrition and Natural Resources. 6 (2011), 107-126.

[18] S. Prasanna, S.M. Jain, Mutant Resources and Mutagenomics in crop plants, Emirates Journal of Food and Agriculture. 29 (2017) 651-657.

[19] H. Satoh et al., Isolation and characterization of starch mutants in rice, Journal of Applied Glycoscience Supplement. 50 (2003) 225-230.

[20] S.D. Johnson et al., Field evaluation of mutagenized rice material, in: J. Jankowicz-Cieslak et al., (Eds.), Biotechnology plant mutation breeding, Springer Nature Switzerland, 2017, pp. $145-157$.

[21] N. Uphoff et al., Improving the phenotypic expression of rice genotypes: Rethinking "intensification" for production systems and selection practices for rice breeding, The Crop Journal. 3 (2015) 174-189.

[22] J.M. Poehlman, Breeding rice, in: J.M. Poehlman, D.A. Sleper (Eds.), Breeding rice field crops, Springer Dordrecht, New York, USA, 1987, pp. 343-374.

[23] J.D. Abacar et al., Variation in yield and physicochemical quality traits among mutants of Japonica rice cultivar Wuyujing 3, Rice Science. 23 (2006) 33-41.

[24] S.D. Koutroubas et al., Grain quality variation and relationships with morpho-physiological traits in rice (Oryza sativa L.) genetic resources in Europe, Field Crops Research. 86 (2004) $115-130$.

[25] Z.Xu et al., Correlations between rice grain shapes and main qualitative characteristics, Acta Agronomica Sinica. 30 (2004) 894-900.

[26] R. Huang et al., Genetic bases of rice grain shape: So many genes, so little known, Trends Plant Science. 18 (2013) 218-226.

[27] W.M. Edzesi et al., Genetic diversity and elite allele mining for grain traits in rice (Oryza sativa L.) by association mapping, Frontier Plant Science. 7 (2016) 1-13.

[28] J. Lou et al., QTL mapping of grain quality traits in rice, Journal Cereal Science. 50 (2009) $145-151$. 
[29] S.D. Kumbhar et al., Genetic diversity and population structure in landraces and improved rice varieties from India, Rice Science. 22 (2005) 99-107.

[30] K.F.M. Salem, A. Sallam, Analysis of population structure and genetic diversity of Egyptian and exotic rice (Oryza sativa L.) genotypes, Comptes Rendus Biologies. 339 (2016) 1-9.

[31] F.S.G. Hashemi et al., The genetic and molecular origin of natural variation for the fragrance trait in an elite Malaysian aromatic rice through quantitative trait loci mapping using SSR and gene-based markers, Gene. 555 (2015) 101-107.

[32] S.F. Lo et al., Genetic resources offer efficient tools for rice functional genomics research, Plant Cell Environment. 39 (2016) 998-1013.

[33] P. Krishnan et al., High-temperature effects on rice growth, yield, and grain quality, in: D.L. Sparks, (Eds.), Advances in Agronomy, Elsevier Inc., Academic Press, 2011, pp. 87-206.

[34] M. Kurowska et al., Molecular analysis of point mutations in a barley genome exposed to MNU and Gamma rays, Mutation Research. 738-739 (2012) 52-70.

[35] T. Suzuki et al., MNU-induced mutant pools and high-performance TILLING enable finding of any gene mutation in rice, Molecular Genetics and Genomics. 279 (2008) 213-223.

[36] P.J.Russel, Extensions of and deviation from Mendelian genetic principles, in: B. Wilbur (Ed.), iGenetics: A Molecular Approach, Pearson Benjamin Cummings San Francisco, USA, 2010, pp. 363-393. 